\title{
EFFECT OF PREGNANCY ON THE FSH RESPONSE TO SYNTHETIC GONADOTROPHIN-RELEASING HORMONE IN EWES
}

\author{
W. A. CHAMLEY, ${ }^{*}$ J. K. FINDLAY,* HELEN JONAS, $\uparrow$ \\ I. A. GUMMING $\ddagger$ AND J. R. GODING*\$ \\ *Reproduction Research Section, Department of Physiology, University of Melbourne, \\ S.S. Cameron Laboratory, Werribee, Victoria 3030, †Medical Research Centre, Prince \\ Henry's Hospital, St Kilda Road, Melbourne, Victoria 3004, and $\ddagger$ Department of \\ Agriculture, State Research Farm, Werribee, Victoria 3030, Australia
}

(Received 14th August 1973)

\begin{abstract}
Summary. Synthetic gonadotrophin-releasing hormone (Gn-RH) was infused at $1.5 \mu \mathrm{g} / \mathrm{hr}$ for $5 \mathrm{hr}$ into ewes at 6,13 and 18 weeks of gestation, around the time of parturition and at 3 and 6 weeks post partum. Changes in the concentration of FSH in plasma were measured by radioimmunoassay. Pituitary response to Gn-RH decreased during gestation with no detectable release of ovine FSH by 18 weeks. There was a marginal response in two of three ewes treated around parturition. No response was observed in two ewes treated at 3 weeks but a slight response was observed in one of the two ewes treated at 6 weeks post partum. These findings suggest that the ovine pituitary is progressively depleted of FSH or becomes refractory to Gn-RH during pregnancy.
\end{abstract}

Although knowledge about the secretion and control of ovine $\mathrm{LH}$ is at an advanced stage (Geschwind, 1972; Goding and his co-authors, 1973), there have been relatively few publications dealing with ovine FSH because of the difficulties encountered in developing suitable assays for this hormone (L'Hermite, Niswender, Reichert \& Midgley, 1972; Salamonsen, Burger, Chamley \& Goding, 1973a).

Plasma concentrations of FSH have been measured throughout the ovine oestrous cycle (L'Hermite et al., 1972; Kerdelhué, Kann \& Jutisz, 1972; Salamonsen and her co-authors, 1973b) and its release in the anoestrous ewe following gonadotrophin-releasing hormone $(\mathrm{Gn}-\mathrm{RH})$ or oestradiol-17 $\beta$ has been reported (Jonas and her co-authors, 1973).

So far no information is available on plasma concentrations of $\mathrm{FSH}$ in the pregnant ewe although the levels of this hormone have been reported to be low at the time of parturition (Chamley, Findlay, Cumming, Buckmaster \& Goding, 1974). This paper reports plasma FSH levels in ewes before and after treatment with Gn-RH during gestation and up to 6 weeks post partum. The changes in plasma LH and the ovarian response to Gn-RH infusion have already been reported (Chamley et al., 1974).

$\$$ Deceased. 
Twelve ewes with exposed carotid loops were used in the experiment. Details on the handling and preparation of these animals have already been given (Chamley et al., 1974).

Three ewes in each of four groups were infused with $\mathrm{Gn}-\mathrm{RH}$ at 6,13 and 18 weeks' gestation and about parturition (one on the day of parturition and one on each of Days 3 and 5 post partum). Two of the ewes treated at 18 weeks and two treated around parturition were infused again at 3 and 6 weeks post partum, respectively.

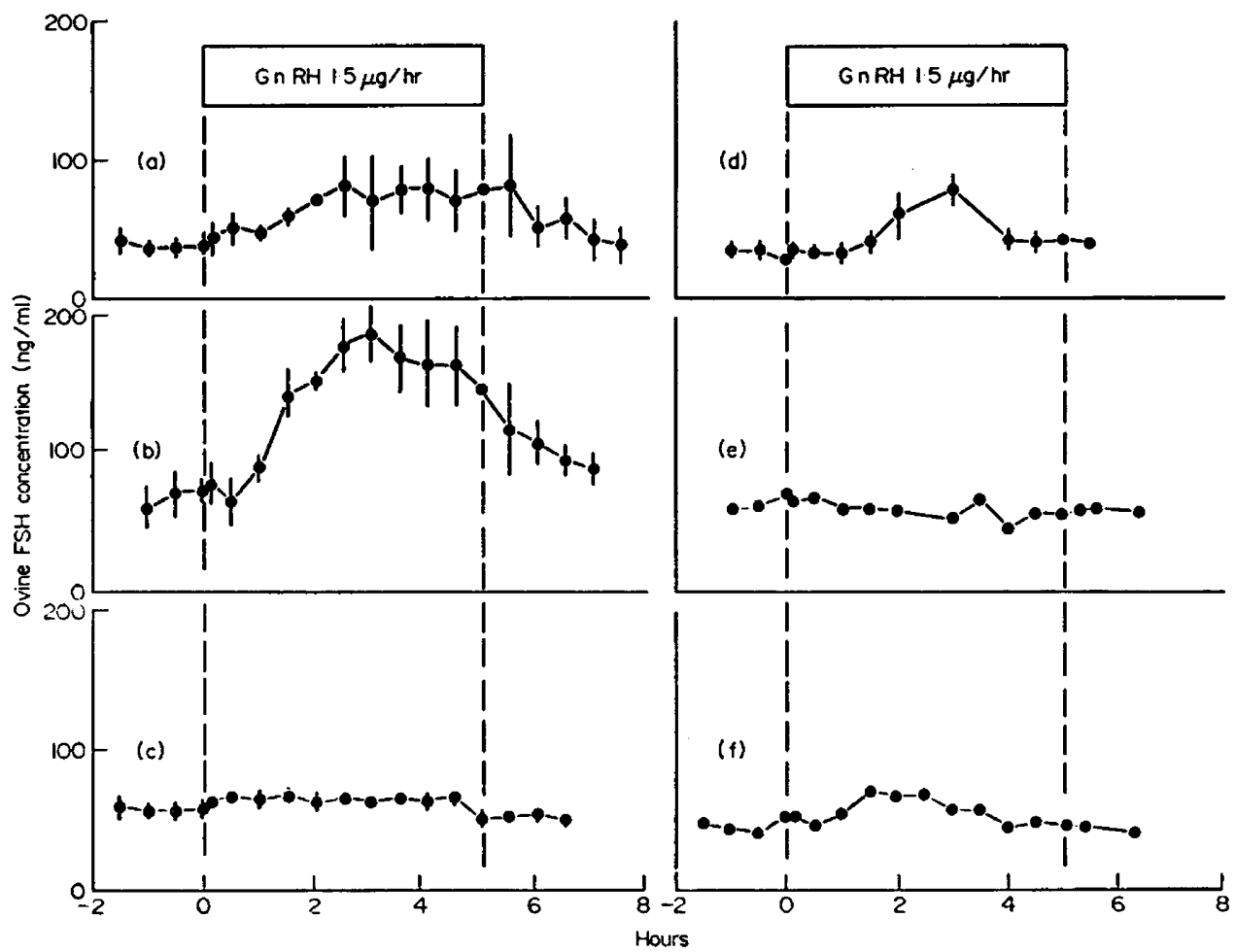

Text-pig. 1. Changes in peripheral plasma FSH (mean \pm S.E.M.) in groups of ewes infused with $\mathrm{Gn}-\mathrm{RH}$ at various stages of pregnancy or post partum: (a), at 6 weeks of gestation; (b), at 13 weeks of gestation; (c), at 18 weeks of gestation; (d), around parturition; (e), at 3 weeks post partum; (f), at 6 weeks post partum. The infusion interval is indicated by the bar.

All ewes received Gn-RH (Abbott, COL-171-B) at a dose rate of $1.5 \mu \mathrm{g} / \mathrm{hr}$ for $5 \mathrm{hr}$ into the carotid artery. The Gn-RH was diluted in heparin-NaCl solution (200 units/ml-0.154 M) immediately before use. Blood sampling was begun at least 60 to $90 \mathrm{~min}$ before the start of the $\mathrm{Gn}-\mathrm{RH}$ infusion and was continued for up to $2 \mathrm{hr}$ after the finish of each infusion period. Half-hourly samples were usually taken throughout each experiment and the plasma was immediately separated and stored at $-15^{\circ} \mathrm{C}$. Plasma FSH was measured in a heterologous radioimmunoassay (Salamonsen et al., 1973b) and is expressed as ng NIH-FSH-S6/ml plasma. Because plasmas from individual animals caused 
various degrees of non-specific antibody precipitation, a correction was made to all values based on the amount of iodinated FSH which was precipitated in tubes containing individual sheep plasma but no antibody. This then allowed for a comparison between groups.

At 6 weeks of gestation, only a slight pituitary response to Gn-RH was detected whereas at 13 weeks of gestation this response was more definite (Text-fig. 1). Infusion of Gn-RH into three ewes at 18 weeks did not cause any appreciable elevation in plasma FSH levels but in those ewes treated around the time of parturition, a marginal FSH response was observed. No response was detected in those ewes treated at 3 weeks, but a slight response was observed in one ewe treated at 6 weeks post partum. Calculation of the mean FSH concentrations measured during the pre-infusion and infusion periods (Table 1) revealed that the changes in FSH were significant only in ewes treated at 6 and 13 weeks' gestation.

Table 1. Mean plasma levels of FSH during a pre-infusion period and during infusion of Gn-RH into ewes at different stages during pregnancy

\begin{tabular}{|c|c|c|c|c|c|c|}
\hline \multirow[b]{2}{*}{ Time of treatment } & \multirow[b]{2}{*}{$\begin{array}{l}\text { No. of } \\
\text { sheep }\end{array}$} & \multicolumn{4}{|c|}{ Plasma FSH $(n g / m l)$} & \multirow[b]{2}{*}{ Significance } \\
\hline & & \multicolumn{2}{|c|}{$\begin{array}{c}\text { Pre-infusion period } \\
(\text { mean } \pm \text { S.E.M. })\end{array}$} & \multicolumn{2}{|c|}{$\begin{array}{c}\text { Infusion period } \\
\text { (mean } \pm \text { S.E.M. })\end{array}$} & \\
\hline $\begin{array}{c}6 \text { weeks (G) } \\
13 \text { weeks (G) } \\
18 \text { weeks (G) } \\
\text { Parturition } \\
3 \text { weeks (PP) } \\
6 \text { weeks (PP) }\end{array}$ & $\begin{array}{l}3 \\
3 \\
3 \\
3 \\
2 \\
2\end{array}$ & $\begin{array}{l}33 \cdot 6 \pm 2 \cdot 9 \\
71 \cdot 6 \pm 4 \cdot 8 \\
59 \cdot 3 \pm 3 \cdot 8 \\
35 \cdot 4 \pm 6 \cdot 9 \\
77 \cdot 1 \pm 7 \cdot 2 \\
69 \cdot 1 \pm 8 \cdot 0\end{array}$ & $\begin{array}{l}(n=12) \\
(n=9) \\
(n=15) \\
(n=9) \\
(n=6) \\
(n=6)\end{array}$ & $\begin{array}{r}59 \cdot 4 \pm 4 \cdot 8 \\
138 \cdot 8 \pm 8 \cdot 7 \\
65 \cdot 6 \pm 1 \cdot 1 \\
46 \cdot 5 \pm 3 \cdot 6 \\
60 \cdot 3 \pm 2 \cdot 5 \\
79 \cdot 5 \pm 4 \cdot 0\end{array}$ & $\begin{array}{l}(n=32) \\
(n=33) \\
(n=33) \\
(n=31) \\
(n=21) \\
(n=20)\end{array}$ & $\begin{array}{l}P<0.05 \\
P<0.05 \\
\text { N.S. } \\
\text { N.S. } \\
\text { N.S. } \\
\text { N.S. }\end{array}$ \\
\hline
\end{tabular}

$n=$ number of plasma samples; $\mathrm{G}=$ gestation; $\mathrm{PP}=$ post partum; N.S. $=$ not significant.

Measurements of plasma LH in these same ewes showed that, as pregnancy continued, there was a progressive decrease in the LH response of the maternal pituitary to Gn-RH, with no detectable response by 18 weeks' gestation but partial recovery by 6 weeks post partum (Chamley et al., 1974).

Recent work in several species has shown that, in the non-pregnant animal, both LH and FSH are released simultaneously in response to Gn-RH (Abe and his co-authors, 1972; Schally, Kastin \& Arimura, 1972; Debeljuk, Arimura \& Schally, 1973; Jonas et al., 1973). Jonas et al. (1973) infused two anoestrous ewes with Gn-RH $(1.5 \mu \mathrm{g} / \mathrm{hr})$ and, in both cases, the plasma FSH rose above basal levels by an increment of $80 \mathrm{ng} / \mathrm{ml}$. The results reported for FSH in this paper, and taken in conjunction with the $\mathrm{LH}$ responses in these same ewes reported elsewhere, suggest that in general this situation also holds in the pregnant sheep.

The reasons for the decrease in FSH response during pregnancy are not yet known but two plausible explanations seem possible. The maternal pituitary could become refractory to Gn-RH during pregnancy and/or pituitary stores of FSH could be reduced. Further studies are being conducted to clarify these findings. 
The authors wish to acknowledge the excellent technical assistance of Miss Julie Robinson with the FSH assay. Dr W. White of Abbott Laboratories, North Chicago, Ill. 60064, U.S.A. donated the Gn-RH. This work was supported by grants from the Australian Wool Research Trust Fund and the Australian Research Grants Committee.

\section{REFERENCES}

Abe, K., Nagata, N., Saito, S., Tanaka, K., Kaneko, T., Shimizu, N. \& Yanaihara, N. (1972) Effects of synthetic luteinizing hormone-releasing hormone on plasma levels of luteinizing hormone and follicle-stimulating hormone in man. Endocr. jap. 19, 77.

Chamley, W. A., Findlay, J. K., Cumming, I. A., Buckmaster, J. M. \& Goding, J. R. (1974) Effect of pregnancy on the LH response to synthetic gonadotropin releasing hormone in the ewe. Endocrinology, (in press).

Debeljuk, L., Arimura, A. \& Schally, A. V. (1973) Stimulation of release of FSH and LH by infusion on LH-RH and some of its analogues. Neuroendocrinology, 11, 130.

Geschwind, I. I. (1972) Dynamics of pituitary gonadotropin secretion. 10th Biennial Symposium on Animal Reproduction, 34, 19.

Goding, J. R., Buckmaster, J. M., Cerini, J. C., Cerini, M. E. D., Ghamley, W. A., Cumming, I. A., Fell, L. R., Findlay, J. K. \& Jonas, H. A. (1973) Gonadotrophins in the ovine oestrous cycle. F. Reprod. Fert., Suppl. 18, 31.

Jonas, H. A., Salamonsen, L. A., Burger, H. G., Chamley, W. A., Cumming, I. A., Findlay, J. K. \& Goding, J. R. (1973) Release of FSH after administration of gonadotrophin-releasing hormone or estradiol to the anestrous ewe. Endocrinology, 92, 862.

Kerdelhué, B., Kann, G. \& Jutisz, M. (1972) Dosage radio-immunologique de la FSH chez le mouton et le rat. In Colloque Inserm, Hormones Glycoproteiques Hypophysaires, p. 177. Eds. M. Jutisz, J. Dolais and G. Rosselin. I.N.S.E.R.M., Paris.

L'Hermite, M., Niswender, G. D., Reichert, L. E. \& Midgley, A. R. (1972) Serum follicle-stimulating hormone in sheep as measured by radioimmunoassay. Biol. Reprod. 6, 325.

Salamonsen, L. A., Burger, H. G., Chamley, W. A. \& Goding, J. R. (1973a) Studies on a radioimmunoassay for ovine follicle stimulating hormone: interference by ovine albumin. Aust. $\mathcal{J}$. exp. Biol. med. Sci. 51, 83.

Salamonsen, L. A., Jonas, H. A., Burger, H. G., Buckmaster, J. M., Chamley, W. A., Cumming, I. A., FindLAY, J. K. \& Goding, J. R. (1973b) A heterologous radioimmunoassay for folliclestimulating hormone: application to measurement of FSH in the ovine estrous cycle and in several other species including man. Endocrinology, 93, 610.

Schally, A. V., Kastin, A. J. \& Arimura, A. (1972) FSH-releasing hormone and LH-releasing hormone. Vitams Horm. 30, 83. 